\title{
Performance of Chilli (Capsicum annuum) cv. 'Krishna Jolokia' as Influenced by Organic Inputs and Microbial Consortium under Assam Condition
}

\author{
Tejaswini Shiriyappagoudar* and Jumi Saikia
}

Department of Horticulture, Assam Agricultural University, Jorhat-13, India

*Corresponding author

\section{Keywords \\ RDF, Microbial consortium, Vermicompost, Chilli, Quality parameters \\ Article Info \\ Accepted: \\ 17 April 2019 \\ Available Online: \\ 10 May 2019}

\section{A B S T R A C T}

A field experiment was conducted at the Experimental Farm, Department of Horticulture, Assam Agricultural University, Jorhat during November 2016 to march 2017 to study the "Performance of Chilli (Capsicum annuum) cv. 'Krishna Jolokia' as influenced by organic inputs and microbial consortium". The results indicated that application of RDF (T1) recorded the highest plant height $(82.38 \mathrm{~cm})$, fruits plant ${ }^{-1}(98.56)$, fruit length $(7.99 \mathrm{~cm})$, fruit girth $(1.01 \mathrm{~cm})$, fruit weight $(2.09 \mathrm{~g})$, fruit yield plant ${ }^{-1}(268.33 \mathrm{~g})$, fruit yield per hectare $(13.07 \mathrm{t})$ with the $\mathrm{B}: \mathrm{C}$ ratio of 4.60 . Among organic treatments the highest plant height $(79.85 \mathrm{~cm})$ found in $\mathrm{T}_{3}$ and the highest number of fruits plant ${ }^{-1}$ (95.63), fruit length $(7.98 \mathrm{~cm})$, fruit girth $(0.98 \mathrm{~cm})$, fruit weight $(1.91 \mathrm{~g})$, fruit yield plant ${ }^{-1}(256.63 \mathrm{~g})$ and fruit yield hectare $^{-1}(12.07 \mathrm{t})$ were found in treatment $\mathrm{T}_{5}$. However, among the quality parameters, the highest ascorbic acid content $\left(80.90 \mathrm{mg} 100 \mathrm{~g}^{-1}\right)$ in $\mathrm{T}_{5}$, moisture content $(91.14 \%)$ in $\mathrm{T}_{1}$ and pungency $(35,000 \mathrm{SHU})$ in $\mathrm{T}_{7}$ were recorded. The present investigation revealed that most of the growth, yield and yield attributes were found highest in treatment receiving RDF. Considering the adverse effect on soil health and environment it is not advisable to use chemical fertilizers at a higher quantity. A study led to the conclusion that good growth, yield with better quality of chilli can be achieved by judicious application of organic, inorganic and biofertilizers.

\section{Introduction}

Chilli (Capsicum annuum var. accuminatum), also called hot pepper is an important cash crop in India and grown for its pungent fruits. Chillies are grown on well-drained loam or sandy loam soils having plenty of organic manure. The soil $\mathrm{pH}$ should be between 6.5 and 7.5. The optimum temperature for chillies is $20^{\circ}-30^{\circ} \mathrm{C}$. Chilli being a major spice with great export potential, the emphasis needs to be given for improving the quality apart from productivity and both can be achieved by organic farming practices which optimize and balance the supply of all the required plant nutrients through efficient utilization of on farm available resources. Use of High Yielding Variety (HYV) and intensive agriculture depleted the nutrient status of the soil. Excessive use of chemical fertilizers to 
obtained high yield resulted in several hazards to the soil, deficiency of micronutrients (Kanwar and Randhawa, 1978) and nutrient imbalance (Singh et al., 1989), ultimately resulting in the reduction of crop yield.

Organic manures are very cheap and easily available, apart from partially fulfilling the nutrient demand, improve soil structure, enhance fertility and promote biological activity. The organic manure gives better quality produce as compared to those grown with the inorganic source of fertilizer (Abusaleha and Shanmugavelu, 1988). But the release of nutrients from organic sources is much slower than chemical fertilizers, for which rapid demand of crop needs cannot be met through organic manures alone. Biofertilizers such as Azospirillum, PSB, VAM, have potential practical applications, which contribute to increasing crop productivity through increased biological nitrogen fixation, increased availability or uptake of nutrients through phosphate solubilization or increased absorption, stimulation of plant growth or by rapid decomposition of organic residues. Several researchers reported that there is no single source of nutrient which can meet the nutrient demand of crops. Therefore all the nutrient sources i.e., organic, inorganic and biofertilizer should be applied in appropriate combination. Good nutrient management often involves a combination of organic and inorganic sources of nutrients.

\section{Materials and Methods}

A field experiment was conducted at the Experimental Farm, Department of Horticulture, Assam Agricultural University, Jorhat during November 2016 to march 2017. The experiment was laid out with Randomized Block Design and replicated three times. There were seven treatments consisting of $T_{1}$ [RDF (120:60:60 kg ha ${ }^{-1}$
NPK + FYM @ $\left.\left.10 \mathrm{t} \mathrm{ha}^{-1}\right)\right], \mathrm{T}_{2}$ (Compost @ $2.5 \mathrm{t} \mathrm{ha}^{-1}+$ microbial consortium), $\mathrm{T}_{3}$ (Compost@ $5 \mathrm{t} \mathrm{ha}^{-1}+$ microbial consortium), $\mathrm{T}_{4}$ (Vermicompost @ $2.5 \mathrm{t} \mathrm{ha}^{-1}+$ microbial consortium), $\mathrm{T}_{5}$ (Vermicompost @ $5 \mathrm{t} \mathrm{ha}^{-1}+$ microbial consortium), $\mathrm{T}_{6}$ (Enriched compost @ $2.5 \mathrm{t} \mathrm{ha}^{-1}$ ) and $\mathrm{T}_{7}$ (Enriched compost @ $5 \mathrm{t}$ $\mathrm{ha}^{-1}$ ). The crop was raised with a spacing of $45 \mathrm{~cm} \times 45 \mathrm{~cm}$ and plot size of $2.5 \mathrm{~m} \times 2.5 \mathrm{~m}$. Standard cultural practices recommended for Chilli was followed uniformly for all the experimental plots. Organic manures, inorganic fertilizers and biofertilizers were applied at different doses as per the treatment requirement. FYM was applied @ $10 \mathrm{t} \mathrm{ha}^{-1}$, compost was applied @ $2.5 \mathrm{tha}^{-1}$ and $5 \mathrm{tha}^{-1}$ and vermicompost was applied @ $2.5 \mathrm{t} \mathrm{ha}^{-1}$ and $5 \mathrm{t} \mathrm{ha}^{-1}$ after final land preparation. Consortium was applied as root treatment. Roots of seedling were dipped in consortium solutions before transplantation. Consortium was applied as root treatment. Roots of seedling were dipped in consortium solutions before transplantation. Consortium applied at the rate of $2 \mathrm{~kg} \mathrm{ha}^{-1}$. Inorganic fertilizers i.e. Urea, SSP, and MOP were applied three days before sowing as a basal application. Half of Urea, full dose of SSP and MOP was applied as basal. The second half of Urea was applied at 30 days after transplanting.

\section{Results and Discussion}

\section{Growth parameters}

The enhancement of vegetative growth with RDF (Table 1) may be due to the direct effect of higher amount of inorganic $\mathrm{N}$, which is an integral part of protein and chlorophyll molecules which might have increased the foliage of the plants and thereby enhanced the photosynthesis. It may also be due to the cell elongation by the presence of nitrogenous compounds. $\mathrm{N}$ being a constituent of amino acids, nucleotides, nucleic acids, a number of co-enzymes, auxins, cytokinins and alkaloids, 
induce cell elongation, cell enlargement and cell division. This increase in $\mathrm{N}$ may further also be ascribed to increased activities through vermicompost and plant bioinoculation, which resulted in production of growth promoting substances and improved nutrient availability for longer period throughout the crop growth and resulted in better photosynthetic activities and ultimately high biomass production (Kumar and Dhar, 2010). Similar findings were obtained by Kondappa et al., (2009) in chilli and Bagale et al., (2014) in tomato.

\section{Yield and yield attributing parameters}

The highest fruit length $(7.99 \mathrm{~cm})$, fruit girth $(1.01 \mathrm{~cm})$ and fruit weight $(2.01 \mathrm{~g})$ was recorded in treatment $\mathrm{T}_{1}$ (Table 1). Among organic treatments the highest fruit length $(7.98 \mathrm{~cm})$, fruit girth $(0.98 \mathrm{~cm})$ and fruit weight $(1.29 \mathrm{~g})$ was observed in $\mathrm{T}_{5}$. This might be due to application of balanced fertilization, which build-up the adequate food reserves for formation and elongation of cells and enhanced the photosynthetic activity by increasing the leaf area and rate of photosynthesis. The synthesised photosynthates might have translocated to the growing fruits having more demand of assimilates which consequently lead to greater length, thickness and weight of fruit.

Efficacy of the inorganic fertilizer was pronounced when they are combined with biofertilizers (Dhawale et al., 2011). These results are in accordance with Reddy et al., (2017) in chilli.

The significant number of seeds was obtained in chilli plants that were supplemented with vermicompost + microbial consortium followed by compost plants inoculated with microbial consortium. The results are up to some extent in agreement with the findings of Sanjutha et al., (2008) who obtained maximum number of seeds per fruit when the high content of $\mathrm{N}$ and $\mathrm{P}$ in organic fertilizers was applied. Similar findings were obtained by Khandaker et al., (2017).

\section{Quality parameters}

Ascorbic acid content (Table 1) in chilli substantially increased with the application of organic fertilizers. This might be due to negative relationship between applied $\mathrm{N}$ levels and vitamin $\mathrm{C}$ content.

This might be due to the fact that plants under organic treatments comparatively have inferior vegetative growth and lesser leaf area than inorganic treatments, so all leaves are well illuminated and act as a source of carbohydrate. Therefore, surplus amount of carbohydrates are available for their conversion to ascorbic acid biosynthesis (Kumar et al., 2015).

Higher moisture content (Table 1) under inorganic treatment can be explained by the fact that inorganic vegetables are larger than the organic ones and thus contain more water (Baskar, 1992). Higher levels of applied N also lead more uptake of moisture due to increased vegetative growth. Similar results were obtained by Kumar et al., (2015).

The treatment $\mathrm{T}_{7}$ fruits recorded $35,000 \mathrm{SHU}$ followed by the treatments $\mathrm{T}_{5}$ (Table 1 ). The variation observed between the treatments due to the presence of microbial inoculants and different level of organic fertilizers. The results obtained in the present study are in accordance with results of Jayasree and George (2006).

\section{Economics of production}

In the present study, the different treatments showed a clear impact on the comparative economics of chilli cultivation. 
Table.1 Performance of CHILLI as influenced by organic inputs and microbial consortium under Assam condition

\begin{tabular}{|c|c|c|c|c|c|c|c|c|c|c|c|c|}
\hline & \multicolumn{8}{|c|}{ Growth and yield } & \multicolumn{3}{|c|}{ Quality } & \multirow[b]{2}{*}{ B:C } \\
\hline Treatment & $\begin{array}{c}\text { Plant } \\
\text { height } \\
(\mathrm{cm})\end{array}$ & $\begin{array}{l}\text { No. of } \\
\text { fruits } \\
\text { plant }_{1}^{-}\end{array}$ & $\begin{array}{c}\text { Fruit } \\
\text { length } \\
(\mathrm{cm})\end{array}$ & $\begin{array}{l}\text { Fruit } \\
\text { girth } \\
(\mathrm{cm})\end{array}$ & $\begin{array}{c}\text { Fruit } \\
\text { weight } \\
\text { (g) }\end{array}$ & $\begin{array}{l}\text { Seeds } \\
\text { fruit }^{-}\end{array}$ & $\begin{array}{c}\text { Fruit } \\
\text { yield } \\
\text { plant }^{-1} \\
(\mathrm{~g})\end{array}$ & $\begin{array}{l}\text { Yield } \\
\left(\mathbf{t ~ h a} \mathbf{~}^{-1}\right)\end{array}$ & $\begin{array}{c}\text { Moisture } \\
(\%)\end{array}$ & $\begin{array}{c}\text { Ascorbic } \\
\text { acid } \\
\left(\mathrm{mg} \mathrm{100g}_{\mathbf{1}}\right)\end{array}$ & $\begin{array}{c}\text { Pungency } \\
\text { (SHU) }\end{array}$ & \\
\hline $\mathbf{T}_{1}$ & 82.38 & 98.56 & 7.99 & 1.01 & 2.09 & 82.47 & 268.33 & 13.07 & 91.14 & 57.97 & 32700 & 4.60 \\
\hline $\mathbf{T}_{2}$ & 69.63 & 82.20 & 7.70 & 0.88 & 1.82 & 92.93 & 170.58 & 7.67 & 80.93 & 76.59 & 33500 & 3.74 \\
\hline $\mathbf{T}_{3}$ & 79.85 & 91.49 & 6.67 & 0.92 & 1.87 & 89.38 & 205.51 & 9.14 & 83.49 & 75.40 & 34000 & 3.76 \\
\hline $\mathbf{T}_{4}$ & 65.83 & 87.63 & 7.52 & 0.85 & 1.85 & 94.59 & 190.85 & 8.58 & 85.98 & 79.10 & 34400 & 3.59 \\
\hline $\mathbf{T}_{5}$ & 77.06 & 95.63 & 7.98 & 0.98 & 1.91 & 96.68 & 256.63 & 12.07 & 86.95 & 80.90 & 34750 & 3.78 \\
\hline $\mathbf{T}_{6}$ & 58.60 & 63.21 & 5.83 & 0.86 & 1.76 & 84.62 & 169.42 & 7.62 & 82.62 & 61.47 & 34500 & 2.03 \\
\hline $\mathbf{T}_{7}$ & 61.98 & 71.78 & 7.95 & 0.95 & 1.80 & 85.75 & 191.58 & 8.62 & 89.29 & 67.75 & 35000 & 1.94 \\
\hline $\operatorname{S.Ed}( \pm)$ & 0.65 & 1.18 & 0.01 & 0.08 & 0.02 & 1.80 & 0.23 & 0.22 & 0.80 & 0.34 & 470. & \\
\hline CD at $5 \%$ & 1.42 & 2.58 & 0.03 & 0.17 & 0.03 & 3.92 & 0.50 & 0.48 & 1.55 & 0.74 & 1025 & \\
\hline
\end{tabular}


Evaluating the relative merit of the different treatments in augmenting the yield revealed that the benefit-cost ratio (4.60) was highest in the treatment $\mathrm{T}_{1}\left[\operatorname{RDF}\left(120: 60: 60 \mathrm{~kg} \mathrm{ha}^{-1} \mathrm{NPK}\right)+\right.$ FYM @ $10 \mathrm{t}^{\mathrm{h}} \mathrm{ha}^{-1}$ ] followed by $\mathrm{T}_{5}$ (Vermicompost @ $5 \mathrm{t} \mathrm{ha}{ }^{-1}+$ microbial consortium) with benefit-cost ratio of 3.78. It might be due to the higher yield as well as higher net income as compared to the other organic treatments. Though the inorganic treatment recorded the maximum yield with the highest benefit cost ratio but there was poor performance in quality parameters. Most of the organic treatments showed better quality as compared to the inorganic treatment.

\section{References}

Abusaleha and Shanmugavelu, K.G. (1988). Studies on the effect of organic vs. Inorganic sources of nitrogen on growth, yield and quality of okra (Abelmoschus esculentus). Indian J. Hort. 45(3-4): 312318.

Bagale, M. M., Kale, V. S., Khardeand, R. P. and Alekar, A. N. (2014). Integrated nutrient management studies in tomato. Bioinfolet. 11(4A): 1054- 1057.

Basker, D. (1992). Comparison of the quality tests between organically and conventional grown fruits and vegetables. American J. Alt. Agric. 7: 129-136.

Dhawale, A.B., Warade, S.D. and Bhangre, K.K. (2011). Integrated nutrient management in Bhindi. Asian J. Hort. 6(1): 145-147.

Jayasree, P. and Annamma, G. (2006). Do biodynamic practices influence yield, quality and economics of cultivation of chilli (Capsicum annuum L.). J. Trop. Agric. 44(1-2): 68-70.

Kanwar, J. S. and Randhawa, N. S. (1978). Micronutrient research in soil and plants in India (Annual Review), Technical Bulletin 50, Indian Council of Agricultural Research, New Delhi.

Khandaker, M. M. and Rohani, F. (2017). Effects of different organic fertilizers on growth, yield and quality of Capsicum annuum L. var. Kulai (Red Chilli Kulai). Biosci. Biotech. Res. Asia 14(1): 185-192.

Kondapa, D., Radder, B.M., Patil, P.L., Hebsur, N.S and Alagundagi, S.C. (2009). Effect of integrated nutrient management on growth, yield and economics of chilli (cv. Byadgi Dabba) in a vertisol. Karnataka J. Agril. Sci. 22(2): 438-440.

Kumar, A. and Dhar, S. (2010). Evaluation of organic and inorganic sources of nutrients in maize (Zea mays) and their residual effect on wheat (Triticum aestivum) under different fertility levels. Indian J. Agril. Sci. 80: 364-371.

Reddy, G. C., Venkatachalapathi, V., Reddy, G. P. D. and Hebbar, S. S. (2017). Study of different organic manure combination on growth and yield of chilli (Capsicum annuum L.). Plant Arch. 17 (1): 472-474.

Sanjutha, S., Subramanian, C., Rani, I. and Maheswari, J. (2008). Integrated Nutrient Management in Andrographis paniculata. Res. J. Agric. Biol. Sci. 4(2): 141-145.

Singh, A. P., Sakal, R. and Sinha, R. B. (1989). Effect of changing cropping pattern and fertility levels on crop yields and micronutrient status of soil after five cycles of crop rotation. Annals of Agricultural Research 10(4): 361-367.

\section{How to cite this article:}

Tejaswini Shiriyappagoudar and Jumi Saikia. 2019. Performance of Chilli (Capsicum annuum) cv. 'Krishna Jolokia' as Influenced by Organic Inputs and Microbial Consortium under Assam Condition. Int.J.Curr.Microbiol.App.Sci. 8(05): 2038-2042. doi: https://doi.org/10.20546/ijcmas.2019.805.236 